\title{
Parental migration, climate and thermal exposure of larvae: spawning in southern regions gives Northeast Arctic cod a warm start
}

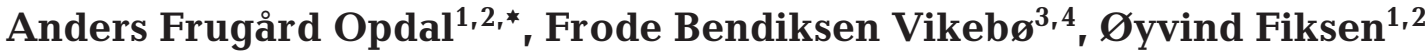 \\ ${ }^{1}$ Uni Research, PO Box 7810, 5020 Bergen, Norway \\ ${ }^{2}$ Department of Biology, University of Bergen, PO Box 7803, 5020 Bergen, Norway \\ ${ }^{3}$ Institute of Marine Research, PO Box 1870, 5817 Bergen, Norway \\ ${ }^{4}$ Bjerknes Centre for Climate Research, Allégaten 55, 5007 Bergen, Norway
}

\begin{abstract}
Temporal variability in environmental conditions met by early life stages is considered a key driver of fluctuations in recruitment and abundance of fish stocks. Variability in spawning grounds selected by the parental population can change the environmental conditions encountered by the offspring, with consequences for recruitment. We compared how changes in spawning ground distribution and interannual climatic variation influenced the temperature exposure of eggs and larvae of Northeast Arctic cod Gadus morhua along the Norwegian coast. By using a general circulation model and $20 \mathrm{yr}$ of forcing data, we tracked eggs and larvae from various spawning grounds and mapped temperature exposure, potential growth rate and theoretical survival probabilities in space and time. We found that the temperature history integrated over the early larval stages decreased by almost $4^{\circ} \mathrm{C}$ from southern to northern spawning grounds. Thus, variations in spawning ground usage have the potential to outweigh the interannual environmental variability, and consequently, shifts in spawning grounds may be more important than climatic variability in determining recruitment success. The long-term northbound shift and truncation of spawning grounds of the Northeast Arctic cod is thought to be caused by a size-selective trawl fishery in the Barents Sea, which promotes smaller and early maturing individuals to spawn farther north. This selection could increase offspring vulnerability to climatic changes, thereby strengthening the link between climate and recruitment.
\end{abstract}

KEY WORDS: Northeast Arctic cod · Gadus morhua · Spawning migration · General circulation model $\cdot$ Offspring fitness $\cdot$ Temperature $\cdot$ Climate

\section{INTRODUCTION}

Environmental heterogeneities are regularly exploited by animals to maximize either feeding rates, reproduction success or both. In polar and subpolar regions, such heterogeneities typically occur across latitudes, promoting regular southbound and northbound migrations in a range of animals, including birds, mammals and fish (Dingle 1996). In reproductive migrations, ideal nursery areas are often less profitable or even completely unsuitable as habitats for the parents, and finding an optimal migration distance that maximises individual fitness becomes a classic trade-off between parental cost and offspring benefit (Lack 1954, Williams 1966). General theory suggests that reproductive strategies, including migration length and location, are optimised decisions based on individual size or physiological state (Dodson 1997), which in fish has been found in a range of families, including clupeids (Nøttestad et al. 1999), 
gadoids (Jørgensen et al. 2008), salmonids (Forseth et al. 1999) and scombrids (Block et al. 2005).

For marine species, translatitudinal spawning migrations are typically directed towards warmer ocean temperatures (i.e. Skjoldal 2004), which is thought to enhance offspring growth rate (Otterlei et al. 1999, Folkvord 2005) and potentially survival (McGurk 1986, Houde 1989). Ever since Hjort's (1914) hypothesis of the 'critical period', the concept that fast growth increases survival probabilities for early stages of fish has been a paradigm in fisheries oceanography (Leggett \& Frank 2008). From an evolutionary perspective, this implies that spawning fish should seek conditions that maximise offspring growth rates through an adaptive choice of spawning time and area (Lasker 1981, Bailey \& Houde 1989, Sinclair \& Iles 1989, Cushing 1990, Jørgensen et al. 2008). However, costly parental investments warrant a concurrent advantage in order to balance costs with potential fitness benefits (Sutherland 1996).

For the Northeast Arctic (NA) cod Gadus morhua, a northern stock of Atlantic cod, this cost is paid in terms of reduced feeding opportunities and energy used for migration between feeding grounds in the Barents Sea and spawning grounds along the Norwegian coast (Jørgensen \& Fiksen 2006, Jørgensen et al. 2008). At present, the vast majority of spawning by NA cod takes place around the Lofoten archipelago $\left(\sim 68^{\circ} \mathrm{N}\right)$ and northwards (Bogstad 2009). However, historic records suggest that up to $60 \%$ of the spawning has taken place in areas south of Lofoten, including Vest-Agder $\left(\sim 59^{\circ} \mathrm{N}\right)$, more than $1000 \mathrm{~km}$ south of Lofoten (Opdal 2010). Based on $104 \mathrm{yr}$ of catch data (1866 to 1969), Opdal (2010) hypothesised that a size-selective trawl fishery in the Barents Sea, which lowered the age at maturation (Heino et al. 2002) and truncated the size distribution (Jørgensen 1990), could have caused this significant change in the spawning ground distribution. Interestingly, changes in the spawning stock age and composition of NA cod may also cause increased influence of climate on recruitment (Ottersen et al. 2006). Longer, more southbound spawning migrations might increase larval survival through increased temperature-dependent growth rates (Opdal et al. 2008). Also, in a state-dependent life history model, Jørgensen et al. (2008) predicted that larger fish and fish in better condition before the spawning migration would profit more from spawning farther south.

In this study, we employ a newly developed ocean model covering the North Sea, Norwegian Sea and the Barents Sea (Vikebø et al. 2010). Coupled to a behavioural model, we track drift trajectories and temperature exposures for virtual eggs and larvae released at all spawning grounds of NA cod, ranging from $71^{\circ} \mathrm{N}$ to $59^{\circ} \mathrm{N}$. This approach allowed us to investigate differences in offspring survival between spawning grounds, as well as understand the potential consequences that historical changes in spawning grounds have had for larval fitness. Because the model includes $20 \mathrm{yr}$ of forcing data, the importance of multiannual environmental variability for offspring survival can be evaluated and compared with the latitudinal effect of spawning ground location.

\section{MATERIALS AND METHODS}

\section{The ocean model}

We used a 3-dimensional hydrodynamic model, the Regional Ocean Modeling System (ROMS) (Haidvogel et al. 2008), in which a model domain covered the North Sea, the Norwegian Sea, the Barents sea and partly the Arctic. This model domain has recently become available with improved resolution $(4 \times$ $4 \mathrm{~km}$ ) and climatological data for $20 \mathrm{yr}$ (1989 to 2008). The model was first presented in Vikebø et al. (2010) in which more elaborate descriptions of the model parameters and performance are available. The model explains observed salinity and temperature transects along the Norwegian coast, and also accurately reproduces known hydrographic and circulation features. The model uses stretched terrain-following coordinates in the vertical, and orthogonal curvilinear coordinates in the horizontal. Monthly mean lateral boundary conditions are taken from a global version of ROMS in the North Atlantic and Arctic oceans ( $20 \mathrm{~km}$ resolution) and include velocity, temperature, salinity and water elevation. Eight dominant tidal constituents (Egbert et al. 1994, Egbert \& Erofeeva 2002) are added at the lateral boundaries. A Lagrangian particle-tracking model (Ådlandsvik \& Sundby 1994) is used to track drift trajectories, depth and temperature exposure of virtual eggs and larvae (particles) released at the different spawning grounds along the coast.

\section{Spawning grounds and larval drift}

Before the 1930s, NA cod spawned over a large range of spawning grounds, including outside the southwestern parts of the Norwegian coast (Opdal 2010). To assess the potential fitness benefits associated with these spawning grounds, and consequently 
the long spawning migrations, we compared drift trajectories and temperature exposures of particles released at the historical as well as contemporary grounds (Fig. 1). The model did not account for prey and predator distribution, and was assumed constant throughout the model domain. Particles were released in batches of 300 per spawning ground every third day from the beginning of March through April, and for each year from 1989 to 2008 in order to capture interannual variation. A total of ca. 100000 particles was released each year. Particles were released in equal numbers at all spawning grounds in all years, and depth and temperature exposure was recorded until 1 September. The subsequent drift and final distribution in the Barents Sea for the different years was used to estimate potential interannual environmental variation from possible spawning sites. Note that the distribution of particles was idealised with equal number of particles across all sites. This is because realised spawning ground distribution is unknown for the time period used for simulations.

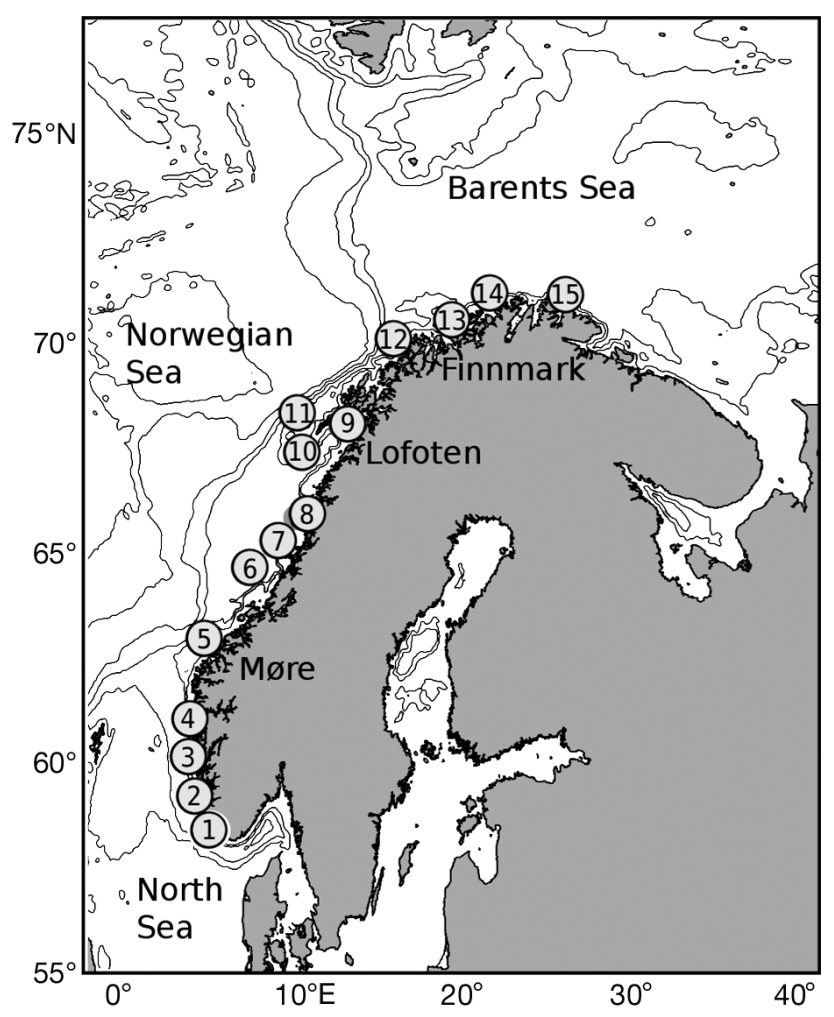

Fig. 1. Gadus morhua. Location of Northeast Arctic (NA) cod spawning grounds along the Norwegian coast, from south to north: (1) Vest-Agder, (2) Rogaland, (3) Hordaland, (4) Sogn, (5) Buagrunnen (Møre), (6) Yttergrunnen, (7) Vikna, (8) Vega, (9) Vestfjorden, (10) Røstbanken, (11) Moskenesgrunnen, (12) Malangsgrunnen, (13) Breivikbotn (WestFinnmark), (14) Central-Finnmark, (15) East-Finnmark. Bottom topography is indicated by $100 \mathrm{~m}$ depth contours

\section{Growth, survival and vertical behaviour}

Larval growth was calculated as a function of temperature (Folkvord 2005) and presented as specific growth rate $\left(\mathrm{SGR}, \mathrm{d}^{-1}\right)$. All individuals are initialized with the same length of $5 \mathrm{~mm}$ and a dry weight of $0.093 \mathrm{mg}$ (Folkvord 2005). To calculate spatial and temporal variation in survival probability to a given size (i.e. the stage-duration hypothesis of recruitment), we used a daily mortality rate $(M)$ for Atlantic cod larvae estimated by Sundby et al. (1989) as $M=0.2 \mathrm{~d}^{-1}$. The larvae were followed to a length of $18 \mathrm{~mm}$, the size to which the growth function remains valid.

Egg buoyancy, and consequently its vertical movement, was calculated as a function of egg density, salinity and turbulence, as described by Thygesen \& Ådlandsvik (2007). The eggs were initialised at $10 \mathrm{~m}$ depth. After the egg stage, which was set to last $22 \mathrm{~d}$ (Iversen \& Danielssen 1984), the larvae exhibited a diel vertical migration pattern (Fig. 2), in which depth and range increased with larval length (Lough \& Potter 1993, Vikebø et al. 2007).

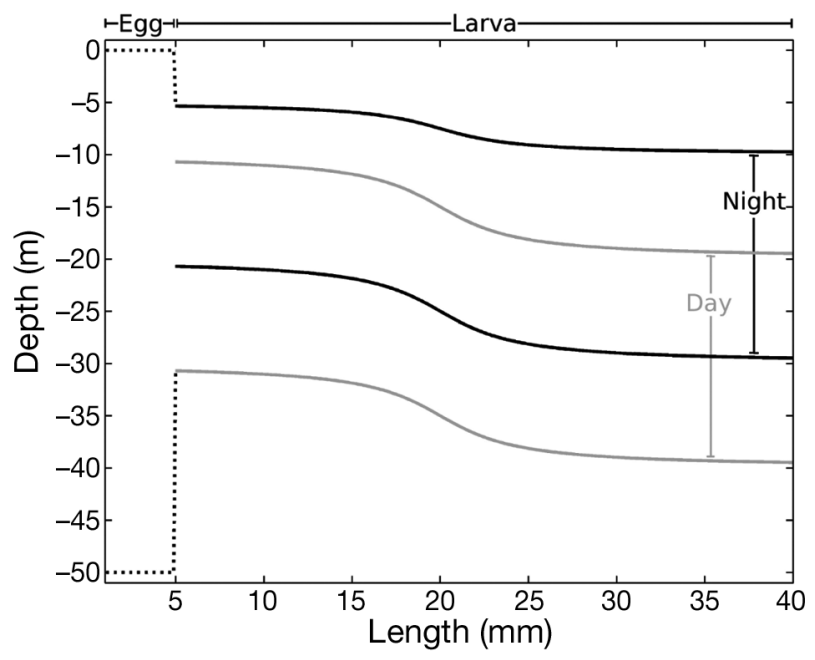

Fig. 2. Gadus morhua. Depth boundaries during NA cod egg stage (black dotted line), and for day (grey line) and night (black line) during larval stage, as a function of larval length. From larval length, upper and lower depth boundaries are set for day and night in concurrence with a size-dependent depth distribution as in Vikebø et al. (2007). Night is defined as light levels $<1.0 \mu \mathrm{mol}$ photons $\mathrm{m}^{-2} \mathrm{~s}^{-1}$. Within the set depth boundaries, larvae move directionally up at night and down at day at a speed of 0.1 body lengths (BL) per time step (dt), where $d t=1 \mathrm{~h}$. In addition, there is also a random vertical movement at a speed of $0.33 \mathrm{BL}$ per time step. In total, the vertical distance moved $(\mathrm{d} Z)$ within a time step is defined as $\mathrm{d} Z / \mathrm{d} t=\alpha \cdot 0.33 \mathrm{BL}-0.1 \mathrm{BL}$, during the day, and $\mathrm{d} Z / \mathrm{d} t=\alpha$. $0.33 \mathrm{BL}+0.1 \mathrm{BL}$, during the night, where $\alpha$ is a behavioural variable defined as random number between -1 and +1 


\section{RESULTS}

\section{Drift patterns and distributions in the Barents Sea}

Buoyant NA cod eggs, which later become vertically mobile larvae, were released from 15 different spawning grounds (Fig. 1) and experienced various drift patterns depending on spawning ground, year and season. From the 20 yr (1989 to 2008) mean larval distribution on 1 September (Fig. 3), it was evident that most eggs and larvae released at the southern spawning grounds (Fig. 3a) distributed closer to the coast and low densities were found in the eastern parts of the Barents Sea. There was also a fraction that experienced a southeastern drift, away from the southern Norwegian coast, which is topographically steered by the deep trench, Norskerenna, at the southern tip of Norway (see Fig. 1 for topography). Larvae from the northern spawning grounds (Fig. 3c) were almost exclusively distributed along the Finnmark coastline and into the eastern Barents Sea, whilst larvae from intermediate grounds (Fig. 3b) had a significant component that ended up in the western Barents Sea.

\section{Temperature exposure, growth and survival}

The more southerly spawning grounds gave rise to higher temperature exposures during the pelagic phase, and interannual variation was apparent (Fig. 4a). Within a single year, the mean temperature exposure could vary by almost $4^{\circ} \mathrm{C}$ between spawning grounds, whilst interannual variation within the same spawning ground never exceeded $2^{\circ} \mathrm{C}$. Also, temperature exposure appeared to vary more between years in the south compared with the north. The cumulative survival probability up to a larval length of $18 \mathrm{~mm}$ was calculated for all years and spawning grounds (Fig. 4b). Larvae spawned in the south under these assumptions experienced an overall lower mortality, and survival probability for eggs and larvae spawned in the most southern areas was 3 to 4 orders of magnitude higher compared with that
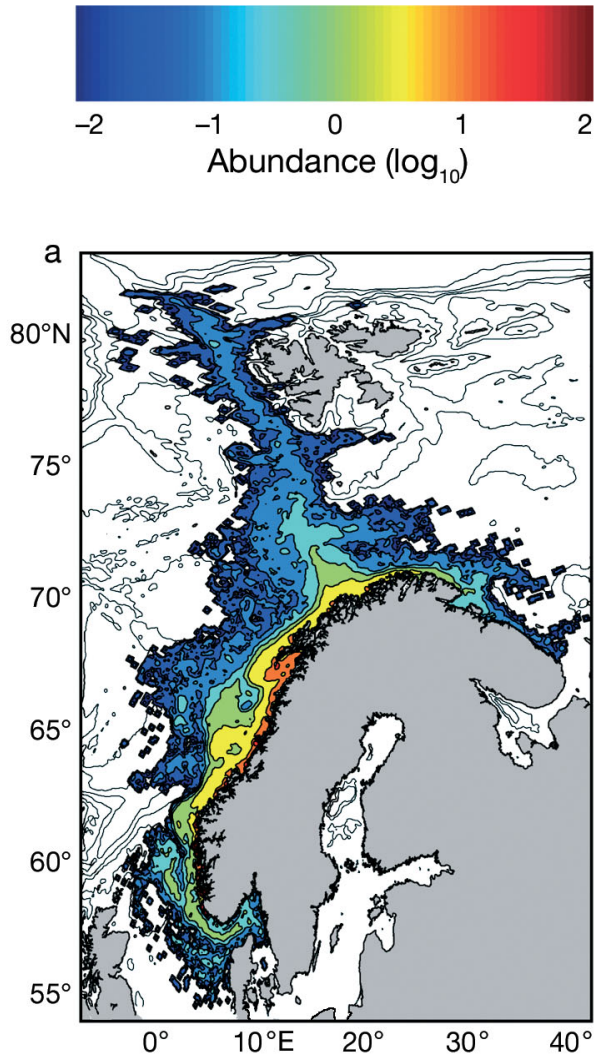
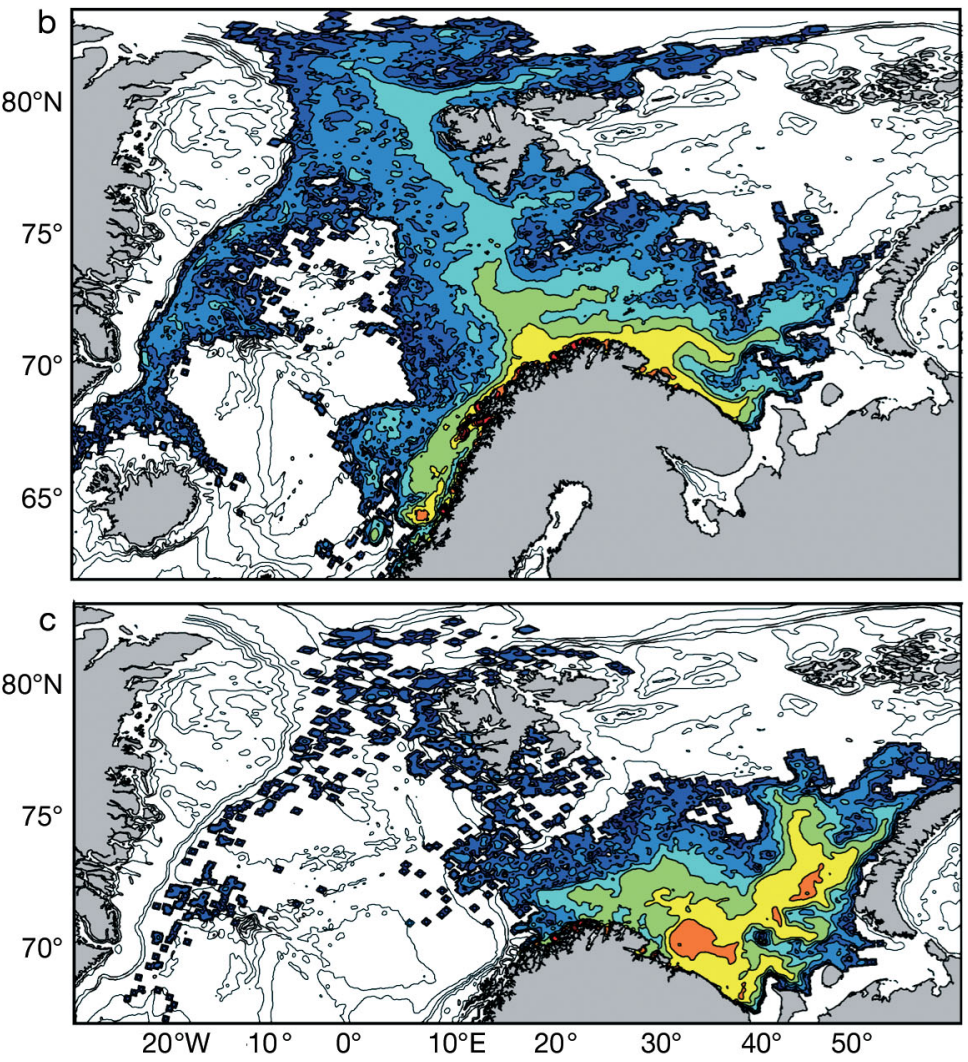

Fig. 3. Gadus morhua. Aggregated mean NA cod larval distributions (1989 to 2008) on 1 September from the spawning grounds (a) 1, 2, 3 and 4, (b) 5, 6, 7, 8, 9, 10 and 11, and (c) 12, 13, 14 and 15 (see Fig. 1). Colours denote the log ${ }_{10}$ transformed abundance (number of individuals) per cell $(4 \times 4 \mathrm{~km})$ 

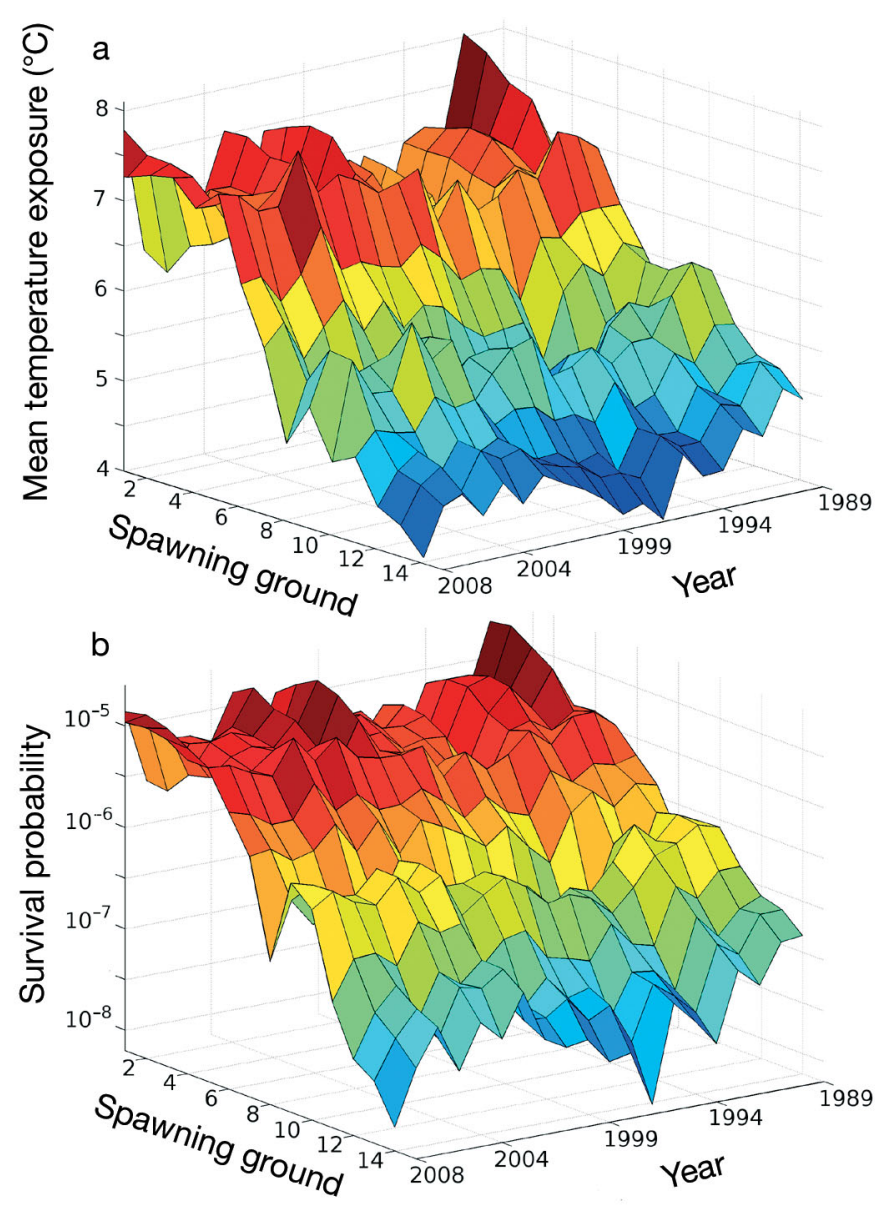

Fig. 4. Gadus morhua. (a) Integrated mean temperature exposure for NA cod eggs and larvae up to $18 \mathrm{~mm}$ length for all years and spawning grounds. (b) Survival probability as a function of spawning ground and year. The cumulative survival probability of larvae up to $18 \mathrm{~mm}$ length was calculated from a fixed daily mortality rate, $M=0.2 \mathrm{~d}^{-1}$ (Sundby et al. 1989), and purely temperature-driven growth (Folkvord 2005). Colouring reflects the value of the vertical axis (blue: low; red: high) to give a clear representation of the surface shape

in the most northern area. The interannual variation in survival was closer to 1 order of magnitude, and weak compared with the latitudinal gradient.

\section{DISCUSSION}

The historically important southern spawning grounds of NA cod may harbour significant fitness benefits in terms of increased temperature conditions, larval growth potential and survival, compared with the contemporary, more northern, dominant spawning grounds. We concluded that latitudinal shifts in spawning migrations by far outweigh interannual fluctuations in terms of temperature exposure for eggs and larvae.

\section{Ocean model and larval drift patterns}

This is the first study to track the environmental history of larvae drifting from all spawning sites of NA cod. Earlier modelling studies (e.g. Ådlandsvik \& Sundby 1994, Vikebø et al. 2007, Opdal et al. 2008) have been limited to only a few years of forcing data and constrained by model domain, as they covered only a small part of the Nordic seas. With $20 \mathrm{yr}$ of climatology data we captured effects of relatively warm and cold periods on drift and temperature exposure during the early life of fish. The hydrodynamic model performed well in reproducing observed interannual ocean temperatures along the Norwegian coast, both from offshore transects (Vikebø et al. 2010) and from stationary temperature recordings along the coast (Ø. Skarseth pers. comm., www.imr.no/forskning/ forskningsdata/stasjoner/). The inclusion of egg buoyancy and larval vertical positioning contributed to a more realistic scenario, considering that variations in vertical behaviour can influence drift patterns and larval distributions (Fiksen et al. 2007, Vikebø et al. 2007, Johansen et al. 2009).

Drift patterns from the spawning grounds were generally northbound towards the Barents Sea, even from the most southern spawning grounds, suggesting that larvae from these grounds could also recruit to the NA cod population in the Barents Sea (Bergstad et al. 1987). However, the most southern areas also experienced some dispersion east and south towards the Swedish coast, away from the Barents Sea. This could indicate that the southern spawning areas selected in the model are not representative of the actual spawning grounds, or that these areas propose a real risk in terms of reduced recruitment to the NA cod stock.

\section{Spawning ground distribution}

We used ocean temperature as a coarse proxy for environmental variation and calculated larval temperature-dependent growth and the cumulative survival for NA cod up to $18 \mathrm{~mm}$ in length. Egg development time and hatching was held constant at $22 \mathrm{~d}$, independent of temperature, and was likely to have caused a hatching date that was too early in the north and too late in the south. However, this assumption is 
considered conservative, and an inclusion of temperature-dependent hatching would in any case strengthen the results of the study considering that egg development time is generally found to decrease with increasing temperature.

Opdal (2010) showed for the time period from 1866 to the mid-1920s, before the onset of the Barents Sea trawl fishery, that between 20 and $60 \%$ of the NA cod's spawner biomass used southern spawning grounds, i.e. spawning grounds 1 to 5 in this study. Because the realised spawning ground distribution for the time period used in the simulation is unknown, we used an idealised distribution in which an equal number of particles were released from each site. Also, demographic effects influencing reproductive characteristics of the spawning stock, such as timing of spawning, fecundity and egg size, are unresolved in the model. However, it is plausible that the relatively longer larval drift routes associated with southern spawning might cause earlier spawning in the south compared with the north. In this case, the relative differences in thermal exposure between north and south would decrease. It is also likely that larger and older individuals, thought to spawn farther south, might experience higher fecundity (Kjesbu et al. 1991), though there may be trade-off of higher energetic cost associated with longer migrations (Jørgensen et al. 2008).

\section{Temperature exposure and offspring survival}

We found that the latitudinal origin of an egg outweighs the interannual climatic influence on the thermal exposure. Therefore, location of NA cod spawning grounds could be more important than climatic variability in determining the ambient environmental conditions of the recruiting age class. It is important to note that while we have assumed a constant mortality rate, there is evidence that mortality in early life stages of fish can increase with temperature (Houde 1989, van der Veer \& Witte 1999). This would reduce larval survival at the southern spawning grounds. However, studies have also shown that early life mortality decreases with size (Folkvord \& Hunter 1986, McGurk 1986, Bailey \& Houde 1989), in which case, larvae spawned in the south would experience relatively higher survival probabilities. A positive relationship between temperature and growth is only valid to a certain threshold, after which increasing temperature is expected to have a negative effect on growth owing to physiological constraints (e.g. Pörtner \& Farrell 2008). Potential future increase in ocean temperatures might shift distributions of NA cod even farther north, as shown for several fish species in the North Sea (Perry et al. 2005).

By assuming a constant, nonlimiting availability of prey, any effect of food is unaccounted for in the model. Although Folkvord (2005) showed that most Atlantic cod larvae captured in the field are growing close to their maximum rate, laboratory experiments have shown that food availability can affect survival of NA cod larvae (e.g. Seljeset et al. 2010). Also, the duration of spatiotemporal overlap between North Atlantic cod larvae and their plankton prey is shown to influence larval survival and consequently recruitment, which indicates that short-term climatic fluctuations are important for larval survival (Kristiansen et al. 2011). This suggests that the short-term (approximately one generation) effect of climate on food availability is also important for the survival of NA cod larvae. However, this effect is not accounted for in our model, as food availability is held constant.

In the case of the NA cod, Sundby \& Nakken (2008) suggested that northbound shifts in spawning locations are due to increasing ocean temperatures. If so, such a shift could serve as a buffer towards the temporal environmental variability. However, Jørgensen et al. (2008) and Opdal (2010) argue that a size-selective trawl fishery in the Barents Sea has truncated the size distribution of the stock and lowered the age of maturation through fisheries-induced evolution, which suggests that large, late-maturing fish and fish in good condition would have optimal spawning locations farther south, compared with small, early maturing fish and those in poorer condition. Opdal (2010) showed that before the onset of the Barents Sea trawl fishery in the 1920s, the NA cod's spawning grounds were distributed along the entire west coast of Norway, and that a northbound shift was evident after the fishery began. The fitness benefits of southern spawning proposed here suggest that intensive harvest and fisheries-induced evolution, leading to truncated and northbound spawning ground distribution, potentially have a greater effect on larval survival and recruitment success than does the long-term climatic influence. Historically, the NA cod's use of a relatively wider range of spawning grounds might have had a dampening effect on potential consequences from environmental fluctuations such as ocean temperatures, food availability or predator abundance (see e.g. Schindler et al. 2010). More specifically, the truncation of spawning ground distribution is suggested to increase offspring vulnerability to climatic changes, thereby strengthening the link between climate and recruitment, as hypothesised for NA cod by Ottersen et al. (2006). 


\section{LITERATURE CITED}

Ådlandsvik B, Sundby S (1994) Modelling the transport of cod larvae from the Lofoten area. ICES Mar Sci Symp 198:379-392

Bailey KM, Houde ED (1989) Predation on eggs and larvae of marine fishes and the recruitment problem. Adv Mar Biol 25:1-83

Bergstad OA, Jorgensen T, Dragesund O (1987) Life-history and ecology of the gadoid resources of the Barents Sea. Fish Res 5:119-161

Block BA, Teo SLH, Walli A, Boustany A and others (2005) Electronic tagging and population structure of Atlantic bluefin tuna. Nature 434:1121-1127

Bogstad B (2009) Northeast Arctic cod. In: Gjøsæter H, Dommasnes A, Falkenhaug $T$, Hauge $M$, Johannesen E, Olsen E, Skagseth $\varnothing$ (eds) Havets ressurser og miljø 2009. Institute of Marine Research, Bergen, p 185

Cushing DH (1990) Plankton production and year-class strength in fish populations: an update of the match/mismatch hypothesis. Adv Mar Biol 26:249-293

Dingle H (1996) Migration: the biology of life on the move. Oxford University Press, Oxford

Dodson JJ (1997) Fish migration: an evolutionary perspective. In: Godin BJ (ed) Behavioural ecology of teleost fishes. Oxford University Press, Oxford, p 10-36

Egbert GD, Erofeeva SY (2002) Efficient inverse modeling of barotropic ocean tides. J Atmos Ocean Technol 19: 183-204

Egbert GD, Bennett AF, Foreman MGG (1994) TOPEX/ POSEIDON tides estimated using a global inverse model. J Geophys Res 99:24821-24852

> Fiksen Ø, Jørgensen C, Kristiansen T, Vikebø F, Huse G (2007) Linking behavioural ecology and oceanography: larval behaviour determines growth, mortality and dispersal. Mar Ecol Prog Ser 347:195-205

Folkvord A (2005) Comparison of size-at-age of larval Atlantic cod (Gadus morhua) from different populations based on size- and temperature-dependent growth models. Can J Fish Aquat Sci 62:1037-1052

Folkvord A, Hunter JR (1986) Size-specific vulnerability of northern anchovy, Engraulis mordax, larvae to predation by fishes. Fish Bull 84:859-869

Forseth T, Næsje TF, Jonsson B, Harsaker K (1999) Juvenile migration in brown trout: a consequence of energetic state. J Anim Ecol 68:783-793

Haidvogel DB, Arango H, Budgell WP, Cornuelle BD and others (2008) Ocean forecasting in terrain-following coordinates: formulation and skill assessment of the Regional Ocean Modeling System. J Comput Phys 227: 3595-3624

Heino M, Dieckmann U, Godø OR (2002) Measuring probabilistic reaction norms for age and size at maturation. Evolution 56:669-678

Hjort J (1914) Fluctuations in the great fisheries of northern Europe viewed in the light of biological research. Rapp P-V Reùn Cons Int Explor Mer 20:1-228

Houde ED (1989) Comparative growth, mortality, and energetics of marine fish larvae: temperature and implied latitudinal effects. Fish Bull 87:471-495

Iversen SA, Danielssen DS (1984) Development and mortality of cod (Gadus morhua L.) eggs and larvae in different temperatures. In: Dahl E, Danielssen DS, Moksness E, Solemdal P (eds) The propagation of cod Gadus morhua L., Vol 1. Flødevigen rapportserie, Institute of Marine
Research, Bergen, p 49-65

> Johansen GO, Godø OR, Skogen MD, Torkelsen T (2009) Using acoustic technology to improve the modelling of the transportation and distribution of juvenile gadoids in the Barents Sea. ICES J Mar Sci 66:1048-1054

Jørgensen T (1990) Long-term changes in age at sexual maturity of Northeast Arctic cod (Gadus morhua L). J Cons Int Explor Mer 46:235-248

Jørgensen C, Fiksen $\varnothing$ (2006) State-dependent energy allocation in cod (Gadus morhua). Can J Fish Aquat Sci 63: 186-199

Jørgensen C, Dunlop ES, Opdal AF, Fiksen $\varnothing$ (2008) The evolution of spawning migrations: state dependence and fishing-induced changes. Ecology 89:3436-3448

Kjesbu OS, Klungsøyr J, Kryvi H, Witthames PR, Walker MG (1991) Fecundity, atresia, and egg size of captive Atlantic cod (Gadus morhua) in relation to proximate body composition. Can J Fish Aquat Sci 48:2333-2343

Kristiansen T, Drinkwater KF, Lough RG, Sundby S (2011) Recruitment variability in North Atlantic cod and matchmismatch dynamics. PLoS ONE 6:e17456

Lack D (1954) The natural regulation of animal numbers. Oxford University Press, London

Lasker R (1981) The role of stable ocean in larval fish survival and subsequent recruitment. In: Lasker $\mathrm{R}$ (ed) Marine fish larvae morphology, ecology, and relation to fisheries, Vol 1. University of Washington Press, Seattle, p 80-87

Leggett WC, Frank KT (2008) Paradigms in fisheries oceanography. Oceanogr Mar Biol Annu Rev 46:331-363

Lough RG, Potter DC (1993) Vertical-distribution patterns and diel migrations of larval and juvenile haddock Melanogrammus aeglefinus and Atlantic cod Gadus morhua on Georges Bank. Fish Bull 91:281-303

> McGurk MD (1986) Natural mortality of marine pelagic fish eggs and larvae: role of spatial patchiness. Mar Ecol Prog Ser 34:227-242

> Nøttestad L, Giske J, Holst JC, Huse G (1999) A lengthbased hypothesis for feeding migrations in pelagic fish. Can J Fish Aquat Sci 56:26-34

- Opdal AF (2010) Fisheries change spawning ground distribution of Northeast Arctic cod. Biol Lett 6:261-264

> Opdal AF, Vikebø F, Fiksen Ø (2008) Relationships between spawning ground identity, latitude and early life thermal exposure in Northeast Arctic cod. J Northwest Atl Fish Sci 41:13-22

> Otterlei E, Nyhammer G, Folkvord A, Stefansson SO (1999) Temperature- and size-dependent growth of larval and early juvenile Atlantic cod (Gadus morhua): a comparative study of Norwegian coastal cod and Northeast Arctic cod. Can J Fish Aquat Sci 56:2099-2111

Ottersen G, Hjermann DO, Stenseth NC (2006) Changes in spawning stock structure strengthen the link between climate and recruitment in a heavily fished cod (Gadus morhua) stock. Fish Oceanogr 15:230-243

Perry AL, Low PJ, Ellis JR, Reynolds JD (2005) Climate change and distribution shifts in marine fishes. Science 308:1912-1915

Pörtner HO, Farrell AP (2008) Physiology and climate change. Science 322:690-692

Schindler DE, Hilborn R, Chasco B, Boatright CP, Quinn TP, Rogers LA, Webster MS (2010) Population diversity and the portfolio effect in an exploited species. Nature 465: 609-612

Seljeset O, Vollset KW, Folkvord A, Geffen AJ (2010) The 
role of prey concentration and size range in the growth and survival of larval cod. Mar Biol Res 6:251-262

Sinclair M, Iles TD (1989) Population regulation and speciation in the oceans. J Cons Int Explor Mer 45:165-175

Skjoldal HR (2004) The Norwegian Sea ecosystem, Vol 1. Tapir Academic Press, Trondheim

Sundby S, Nakken O (2008) Spatial shifts in spawning habitats of Arcto-Norwegian cod related to multidecadal climate oscillations and climate change. ICES J Mar Sci 65: 953-962

Sundby S, Bjørke H, Soldal AV, Olsen S (1989) Mortality rates during the early life stages and year class strength of the North-East Arctic cod (Gadus morhua L.). Rapp P-V Reùn Cons Int Explor Mer 191:351-358

Sutherland WJ (1996) From individual behaviour to population ecology. Oxford University Press, Oxford

Thygesen UH, Ådlandsvik B (2007) Simulating vertical turbulent dispersal with finite volumes and binned random

Editorial responsibility: Jake Rice,

Ottawa, Ontario, Canada walks. Mar Ecol Prog Ser 347:145-153

van der Veer HW, Witte JIL (1999) Year-class strength of plaice Pleuronectes platessa in the Southern Bight of the North Sea: a validation and analysis of the inverse relationship with winter seawater temperature. Mar Ecol Prog Ser 184:245-257

> Vikebø FB, Jørgensen C, Kristiansen T, Fiksen Ø (2007) Drift, growth and survival of larval Northeast Arctic cod with simple rules of behaviour. Mar Ecol Prog Ser 347: 207-219

Vikebø FB, Husebø A, Slotte A, Stenevik EK, Lien VS (2010) Effect of hatching date, vertical distribution, and interannual variation in physical forcing on northward displacement and temperature conditions of Norwegian springspawning herring larvae. ICES J Mar Sci 67:1948-1956

Williams GC (1966) Natural selection costs of reproduction and a refinement of Lack's principle. Am Nat 100: 687-690

Submitted: May 9, 2011; Accepted: August 4, 2011 Proofs received from author(s): October 13, 2011 